\title{
Key-Descriptors for the Functioning of a Mediterranean Reservoir: The Case of the New Lake Karla-Greece
}

\author{
Maria Chamoglou • Theodoti Papadimitriou • \\ Ifigenia Kagalou
}

Received: 11 November 2013 / Accepted: 23 December 2013 /Published online: 22 May 2014

(C) Springer International Publishing Switzerland 2014

\begin{abstract}
Mediterranean freshwater systems face the lack of water as an important threat along with other multiple stressors (e.g., eutrophication, salinization, changes in hydrology and morphology) mainly attributed to human intervention. These stressors have been maximized due to the climate variability, the progressive diminishing of freshwater availability and the topography characteristics. Lake Karla is an example of a lake ecosystem which was dried in the 1960s and now is restored, facing various anthropogenic pressures. During the last 2 years (2010-2012) a 'new' shallow lake was reconstructed experiencing extensive alterations associated with land use changes, hydrological flow modifications, over-enrichment of chemicals, inappropriate management of biological resources. In terms of conservation value, Lake Karla is listed in Natura 2000 sites as a protected area. The aim of the present paper is to identify the key-descriptors highlighting the function of the new system, thus providing necessary 'tools' for an effective management plan. A 12-month monitoring study has taken place revealing the hydrological profile, the excess of in-lake nutrient concentrations, mainly attributed to the inflows and surface runoff, thus promoting a cultural eutrophication as it is also expressed by the high chlorophyll values. Relationships between nutrients and chlorophyll-a concentrations highlight the system's functioning. Yet, the classification of Lake Karla, as a highly modified water body, according to the Water Framework Directive, is discussed. Lake Karla serves as a paradigm on the multiple stressor effects and the complexity of biological restoration even though physical restoration has been established.
\end{abstract}

Keywords Trophic state $\cdot$ Nutrients $\cdot$ Hydrological characteristics $\cdot$ Restored lake Karla

\footnotetext{
M. Chamoglou

Department of Ichthyology \& Aquatic Environment, University of Thessaly, 38446 Volos, Greece

T. Papadimitriou

Management Body of Ecodevelopment, Area of Karla, Mavrovouni, Kefalovriso, Velestino, Greece

I. Kagalou $(\bowtie)$

Department of Civil Engineering, School of Engineering, Democritus University of Thrace, 67100 Xanthi, Greece

e-mail: ikagkalo@civil.duth.gr
} 


\section{Introduction}

Reservoirs have been found in many Mediterranean regions, since the 5th century BC. These ecosystems are important contributors to groundwater, local and regional weather stability, preservation of biodiversity and water supply (Skinner and Zalewski 1995).

Reservoirs, like natural lakes, on the scale of human life are permanent features of the landscape. Reservoirs born on human needs, mature rapidly and geologically depict a small life span. Both these lentic systems are strongly linked to the catchment area, accepting inputs, trapping and recycling nutrients, organic load and deposits of terrestrial matter, thus, promoting a cultural eutrophication process (Harper 1992). Consequently, environmental conditions in the catchment along with hydrodynamic processes and geomorphology are shaping the responses of the biotic elements, the biotic stability of the system as well as the natural succession processes (Wetzel 1990).

The Mediterranean region is one of the most sensitive areas regarding extreme climate changes, due to the marked decrease and fluctuation in seasonal precipitation (Sánchez et al. 2004). The increased need of water for human activities (e.g., agricultural, urban and industrial use) coupled with the water scarcity, have led many aquatic systems to display a progressive eutrophication (Beklioglu et al. 2007). Álvarez- Cobelas et al. (2005) gave an overview of the contrast between the Mediterranean and other temperate limnosystems, taking into accounts climatic variability and pinpointing the distinctiveness of the Mediterranean climate. The Mediterranean region encompasses severe water resource problems (Loukas et al. 2007) including pollution by nutrients, leaching of pesticides, as well as intrusion of salt water into fresh water ecosystems (Kagalou et al. 2008). It is also claimed that agriculture is the greatest consumer of water in this region with use significantly above the world's average- more than $80 \%$ of water resources are allocated to agriculture (Araus 2004). These manmade activities cause, therefore, adverse environmental impacts such as soil degradation, salinization of water by sea water intrusion and deterioration in water quality such as eutrophication (Jouni 2011).

While reservoirs located in Northern Europe usually serve hydropower needs, in the Southern Mediterranean area they are generally smaller, also accommodating irrigation and water supplying needs. These latter reservoirs are more likely to be subject to higher nutrient loads and their uses are particularly sensitive to eutrophication issues (EEA 1999). In semi-arid and arid areas, reservoirs often represent quite extreme environments because of pronounced changes in water levels with associated periods of very high nutrient concentrations and sediment-loaded water (Guntner et al. 2004).

Lake Karla (Thessaly, Greece) was listed among the shallow lakes in Greece until 1962, when complete drying of the lake took place, creating more agricultural land; it is now under restoration to establish a 'new' reservoir. Prior to the 1960s, Lake Karla was considered as one of the most important ecosystems in the region, serving as a natural reservoir, providing water storage and recharging to groundwater. Accordingly, the importance of restoring this water body and reversing the environmental conditions caused by manmade activities was considered an environmental project of high importance by the European Union (Papadimitriou et al. 2013). The structure and functioning of the new Karla reservoir is linked with the Pinios River, directly feeding it, but also the reservoir receives runoff from its drainage basin along with effluents from the most significant agricultural area in Greece (Sidiropoulos et al. 2012). After 2 years of re-filling, drastic eutrophication occurred in Karla reservoir, with long-standing dominance of cyanobacteria and associated toxins (Oikonomou et al. 2012; Papadimitriou et al. 2013). The occurrence of cyanobacteria and of cyanotoxins is especially important because the reservoir is going to be used for irrigation, fisheries and recreation. During the first year of the lake refilling, the dominant cyanobacterial species Anabaenopsis elenkinii, Sphaerospermopsis 
aphanizomenoides and Planktothrix agardhii were associated with the production of cyanotoxins (microcystins) detected in both water and fish tissues, posing low risk adverse health effects for recreational activities and high risk for fish consumption (Papadimitriou et al. 2013; Mitsoura et al. 2013). Since we have not yet solid evidence about the new function of the lake, there is an urgent appeal for research concerning its hydro-ecological features. The objectives of the present study are to: a) describe the water chemistry dynamics of lake Karla, evaluating also its trophic status; and b) identify the key-descriptors highlighting the function of the new system, thus providing the necessary 'tools' for an effective management plan.

\section{Methodology}

\subsection{The Study Area}

Lake Karla occupied the lowest part of Thessaly plain and was considered as one of the most important wetlands in Greece until 1962. Surface runoff from the watershed and floodwaters of the Pinios River (discharging via the Asmaki ditch) supplied the lake with large quantities of freshwater. In 1962, a complete drying of the lake took place in order to increase agricultural land use surface. The re-constructed Lake Karla is now located on the lower depression of the Thessaly plain in the Region of Central Greece. It lies between latitude $39^{\circ} 26^{\prime} 49^{\prime \prime}$ to $39^{\circ} 32^{\prime} 03^{\prime}$ $\mathrm{N}$ and longitude $22^{\circ} 46^{\prime} 47^{\prime \prime}$ to $23^{\circ} 51^{\prime} 50^{\prime \prime} \mathrm{E}$, and has a surface area of $38 \mathrm{~km}^{2}$, while its perimeter is $30.55 \mathrm{~km}$. The hydrological basin of Lake Karla has a total area of $1,171 \mathrm{~km}^{2}$, of which more than $600 \mathrm{~km}^{2}$ comprise a southern flat plain, while the east part is surrounded by mountains and hills. It is characterized by its shallow depth, with a maximum water depth of $4.5 \mathrm{~m}$ and a mean depth of $2 \mathrm{~m}$. At the present, the main water source for Lake Karla is Pinios River. The lake also receives surface runoff from the surrounding area-which is mainly agricultural - and inflows of perennial streams that drain from the surrounding mountainous land; the lake has no natural outflow.

\subsection{Sampling and Laboratory Analysis}

Monthly water samples for nutrients and chlorophyll-a were collected during the period January 2012 to December 2012. Also, monthly average precipitation, monthly average water volume and monthly lake level were recorded. In August, bi-weekly samples were taken in order to reflect the potential variability during the warmest-driest month. Samples were taken from the upper $50 \mathrm{~cm}$ of the water column at three representative sampling stations. Station 1 (ST1) is a pelagic station, located near the centre of the lake. Its maximum depth is $2.5 \mathrm{~m}$. Station 2 (ST2) is a littoral station, located on the southwest shore of Karla reservoir, which is near the secondary input of water that enters by gravity flow into the lake through a drainage channel. Station 3 (ST3) is also a littoral station, located on the north-east shore of Lake Karla and was selected to represent the part of the lake that is exposed to runoff coming from livestock grazing, animal sheds and the mountainous land in the eastern part of Lake Karla catchment (Fig. 1).

Temperature, $\mathrm{pH}$, dissolved oxygen concentration (D.O.) and conductivity were measured in situ by electrode probes (YSI, USA). Concentrations of nitrate $\left(\mathrm{NO}_{3}-\mathrm{N}\right)$, ammonia $\left(\mathrm{NH}_{4}-\mathrm{N}\right)$ and Total Phosphorus (TP) in lake water were determined from water sample analyses according to Standard Methods (APHA 2005). Dissolved Inorganic Nitrogen (DIN) was calculated as the sum of $\mathrm{N}-\mathrm{NO}_{3}$ and $\mathrm{NH}_{4}-\mathrm{N}\left(\mathrm{N}-\mathrm{NO}_{2}\right.$ values were negligible). Water transparency, expressed as Secchi Depth (SD), was measured with a Secchi Disk. The content of the 


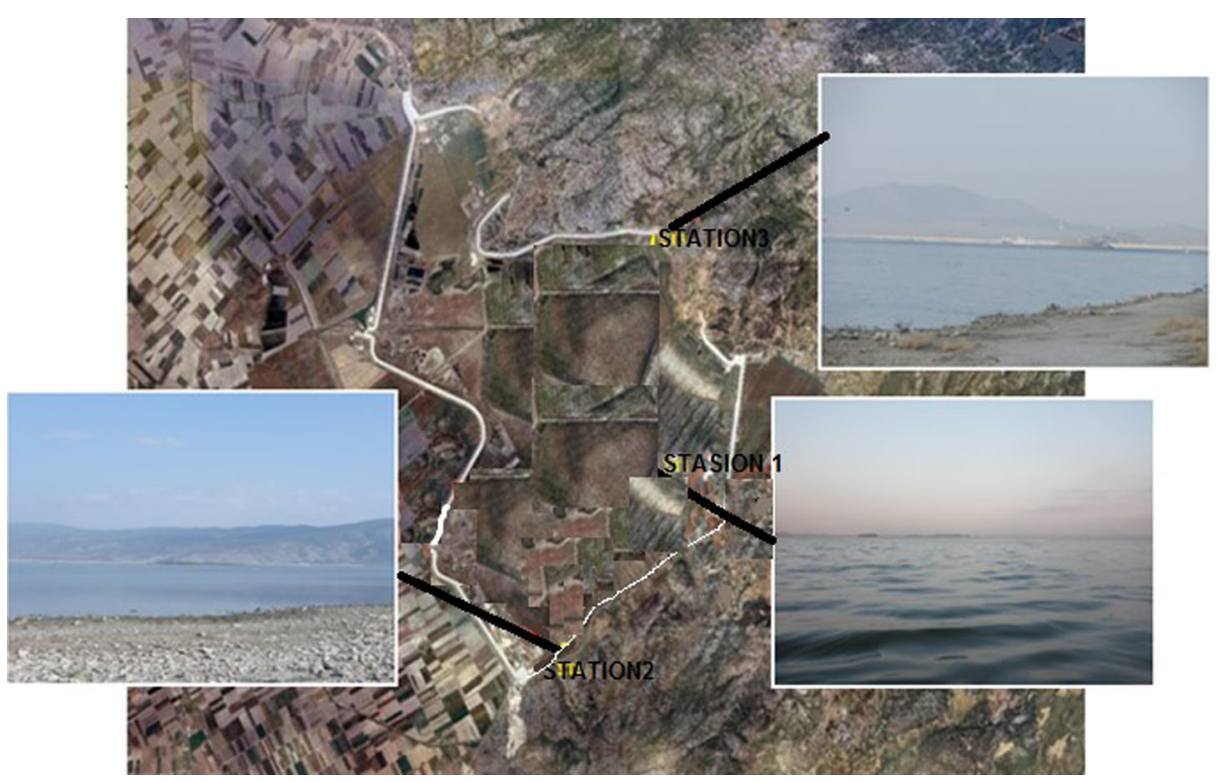

Fig. 1 Map of Lake Karla, where the three sampling stations are shown

algal biomass in water samples was estimated by Chlorophyll- $a$. The pigment was extracted with $95 \%$ acetone after filtration of $500 \mathrm{~mL}$ of sample water on GF/F filters and measured spectrophotometrically (APHA 2005).

\section{Statistics}

Data were $\log (\mathrm{x}+1)$ transformed in order to minimize the effect of different measurement units and obtain homogeneity of the variance. Seasonal and spatial variations were tested by oneway ANOVA (effects: seasons, stations), followed by Tukey HSD post hoc.

Relations between water quality parameters were tested by Pearson's correlation. Principal component analysis (PCA, correlation matrix) was performed to access the importance of each measured variable to explain the variance of the data. Statistical analyses were performed with SPSS Statistics 20, except for PCA (Multivariate Statistical Package-MVSP, KCS).

\section{Results and Discussion}

The monthly variation of the examined parameters is presented in Fig. 2. Monthly rainfall during the studied period ranged between $0 \mathrm{~mm}$ in October and $101 \mathrm{~mm}$ in November (Fig. 2). Water inflows from Pinios River and from the watershed runoff through a system of constructed ditches as well as through collector channels. The discharge from Inflow 1 contained several peaks coinciding with the precipitation pattern (Fig. 2) while the discharge from Inflow 2 was greater during the months April- May. The lake stored water volume ranged between $29.5 \times 10^{6}$ and $56 \times 10^{6} \mathrm{~m}^{3}$, while the lake level at the full supply level (FSL) of $46.35 \mathrm{~m}$ was recorded in June. The lake level started to increase from March 2012 just after the first inflow event in February 2012. 

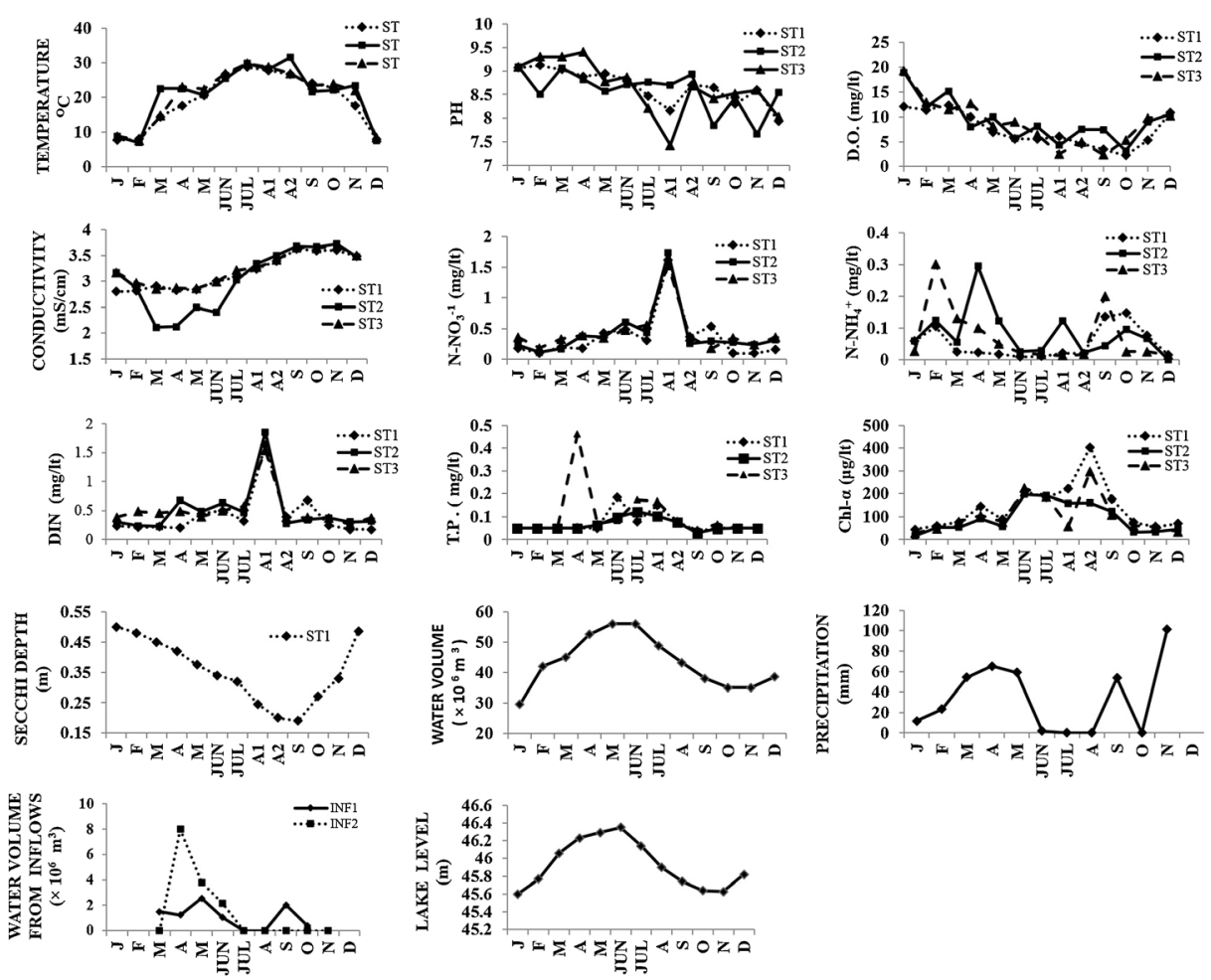

Fig. 2 Monthly variation of conductivity, $\mathrm{pH}$, temperature, dissolved oxygen, conductivity, nitrate-N, ammonia$\mathrm{N}$, total phosphorus, Chl- $\alpha$, Dissolved Inorganic Nitrogen, Secchi Depth, water volume and precipitation for the year 2012

Functioning of water bodies depends on water balance, which depends on groundwater and surface water hydrology. The watershed area of Lake Karla is characterized as intensive productivity area, thus, requiring over-pumping of groundwater which has led to deterioration of the aquifer during the past decades. During the winter period, precipitation feeds the lake while, at the moment, the Karla reservoir experiences intra-annual water level fluctuations due to the management of the inflows from Pinios river through a system of constructed ditches.

The water temperature ranged from $7{ }^{\circ} \mathrm{C}$ in February to $31.5^{\circ} \mathrm{C}$ in August. The dissolved oxygen (D.O.) concentration ranged between $2.24 \mathrm{mg} / \mathrm{L}$ (in October) and $18.0 \mathrm{mg} / \mathrm{L}$ (in January) (Fig. 2) and it was highly correlated with Secchi depth $(r=0.851 ; p<0.01)$ explaining that water clarity coincides with high D.O. values. The $\mathrm{pH}$ values were ranged between 7.43 and 9.12 without any apparent seasonal variation. The water conductivity was relatively high, ranging between $2.11 \mathrm{mS} / \mathrm{cm}$ (in March) and $3.68 \mathrm{mS} / \mathrm{cm}$ (in September) (Fig. 2) which may be attributed to the geological profile of the whole catchment (Jouni 2011) but also to runoff from the surrounding agricultural area. The values of the in situ measured parameters showed no differences among stations, thus suggesting the absence of any spatial heterogeneity. With regard to nutrient concentrations, Nitrate- $\mathrm{N}$ was the most important form in the DIN pool varying between 0.1 and $1.7 \mathrm{mg} / \mathrm{L}$, exhibiting higher values during the summer months. Nitrate-N correlated with water temperature $(r=0.401 ; p<0.05)$, thus, indicating high decomposition rates during the warm period. Ammonia-N ranged from 0.011 to $0.3 \mathrm{mg} / \mathrm{L}$, exhibiting higher values during the spring. Also, during February and April, Ammonia-N concentrations 
were above the value of $0.2 \mathrm{mg} / \mathrm{L}$, which is the limiting value for fish intoxication, according to the European Directive 2006/44. Total Phosphorus (TP) ranged from 0.05 to $0.461 \mathrm{mg} / \mathrm{L}$, peaking in April (Fig. 2). The values of nutrients showed no differences among stations. Chlorophyll- $\alpha$ ranged between 16.7 and $403.58 \mathrm{mg} / \mathrm{L}$, with higher values during the warmer months indicating a strong hypertrophication (Fig. 2). The seasonal pattern of Chlorophyll- $\alpha$ was also confirmed by correlation analysis, linking it with water temperature $(r=0.549$; $p<0.01$ ). Secchi depth varied between 0.19 and $0.5 \mathrm{~m}$ with low values persisting during the summer months, thus reflecting the turbid character of the water body.

A reduced water transparency due to organic material and plankton, along with the presence of frequent algal blooms (Anabaena sp., Aphanizomenon sp.) reported by Ananiadis (1956), suggests that the lake has been eutrophic since at least the 1950s. The water analysis through the water column, carried out in 1955, revealed that Karla was relatively rich in dissolved nutrients and low dissolved oxygen concentrations near the bottom, classifying it as eutrophic. According to the present nutrient and chlorophyll-a profile, it becomes clear that Lake Karla is a eutrophicated system, with apparent signals of hypertrophication during the warm period (OECD 1982). The absence of any outlet, and thus of any flushing process, leads to a high water residence time, strengthening the eutrophic conditions. During the study period, the lake reached a maximum depth of $2.5 \mathrm{~m}$, rendering Lake Karla a shallow system, with the typical temperature pattern of the Mediterranean region, i.e., two well-separated hydrological periods. Hydrological balance, in terms of quantity and periodicity of the water resource appear to be a strong control factor on the concentrations of major ions and nutrients (nitrogen and phosphorus) for most shallow lakes and reservoirs of Mediterranean climate (Beklioglu et al. 2007). As a result, sensitivity to hydrological conditions has also significant consequences for the in-lake concentration of nutrients. In shallow Mediterranean lakes, nutrient inputs from the catchment occur mainly in winter-spring due to high precipitation, while in cases of outflow absence, they act as nutrient sinks. The reduction of the residence time by regulating the annual timing of the inflows and outflows could certainly aim at the improvement of water quality in Lake Karla. This is considered as an emergent issue concerning the future management process.

Chiaudani and Premazzi (1986) consider that phosphorus is the key element, even though many factors determine aquatic ecosystem plant biomass. In unaffected lakes and reservoirs, the concentration of phosphorus is below $25 \mu \mathrm{g} / \mathrm{L}$ (EEA 1999). Lake Karla's phosphorus concentration is very far exceeding this limit value, suggesting strong anthropogenic impact. Furthermore, Jouni (2011) reported phosphorus accumulation in the bottom sediment of the lake, suggesting an internal loading process. Nutrient release from the sediment has been reported for lakes, lagoons and estuaries highlighting that, it might be an important input of nutrients (Beklioglu et al. 2007; Gikas et al. 2006; Markou et al. 2007). Regarding the Mediterranean systems, the low water level will often enhance resuspension and, together with the higher temperature, amplify the sediment release of nutrients, especially of phosphorus (Ozen et al. 2010). Since lake Karla has experienced a long period of dryness accompanied by intense application of fertilizers, the nutrient release from the sediment and the enrichment of the water column should be tested in order to eliminate the internal loading process. Nitrogen plays a secondary role, but can become important at a high level of eutrophication. In Lake Karla, both nutrients are in excess, thus favouring the excess of algal biomass and specifically of the cyanobacteria, whose occurrence and persistence are linked to high eutrophicated conditions (Papadimitriou et al. 2013).

PCA has been a widely used tool to identify relevant groups of water and the most important factors affecting water quality variation. A PCA was performed to evaluate the main parameters influencing water quality in Lake Karla (Fig. 3). The first two components explained $92.7 \%$ of the system's variability. The first axis accounted for $57.7 \%$ of the total variance and chlorophyll-a, DIN, 
nitrate and temperature were the main factors contributing to it. The second axis explained $35 \%$ of the data variation and was highly correlated with ammonium-nitrogen, Secchi depth, TP and conductivity. The PCA also shows separation between summer and winter, related to ammonium, Secchi depth, TP and Conductivity. It is characteristic that the clear water phase of the lake, in terms of Secchi depth, is related to the Spring period and further to adequate dissolved oxygen content. In addition, the PCA analysis and, generally, the multiparametric response functions clearly demonstrate their usefulness as "tools" in order to describe the complexity and the variability of the shallow aquatic ecosystems (Gikas et al. 2006; Scheffer et al. 1993, 2001).

The Water Framework Directive (WFD, EC, 2000/60) is potentially the most significant piece of legislation ever enacted in Europe in the interests of conservation of fresh and saline ecosystems. The aim of the WFD is to ensure sustainable management of groundwater, freshwater and marine water in the European Union, so that a minimum "good ecological status" is obtained by year 2015. The characterization of the ecological status of each water body in Greece has become a legal imperative after the approval of the WFD.

Lake Karla, in terms of typology, is considered as an artificial lake, and furthermore, as a highly modified system. Since there are not established pristine reference conditions for this lake type based on biological data, as it is suggested by the WFD, the classification into categories is quite unsafe. Based on the present algal biomass data, comparable data from similar case studies, and based on our experience from our biological data during the same monitoring period (Papadimitriou et al. 2013; Oikonomou et al. 2012), we could argue that the water status of lake Karla falls into 'poor' or 'bad' category. River Basin Management Plan of Thessaly Water District provides also valuable scientific information about regional water bodies classification (Ministry of Environment 2012) based on the physicochemical parameters. Taking into consideration the boundary values suggested only for Secchi depth, Total

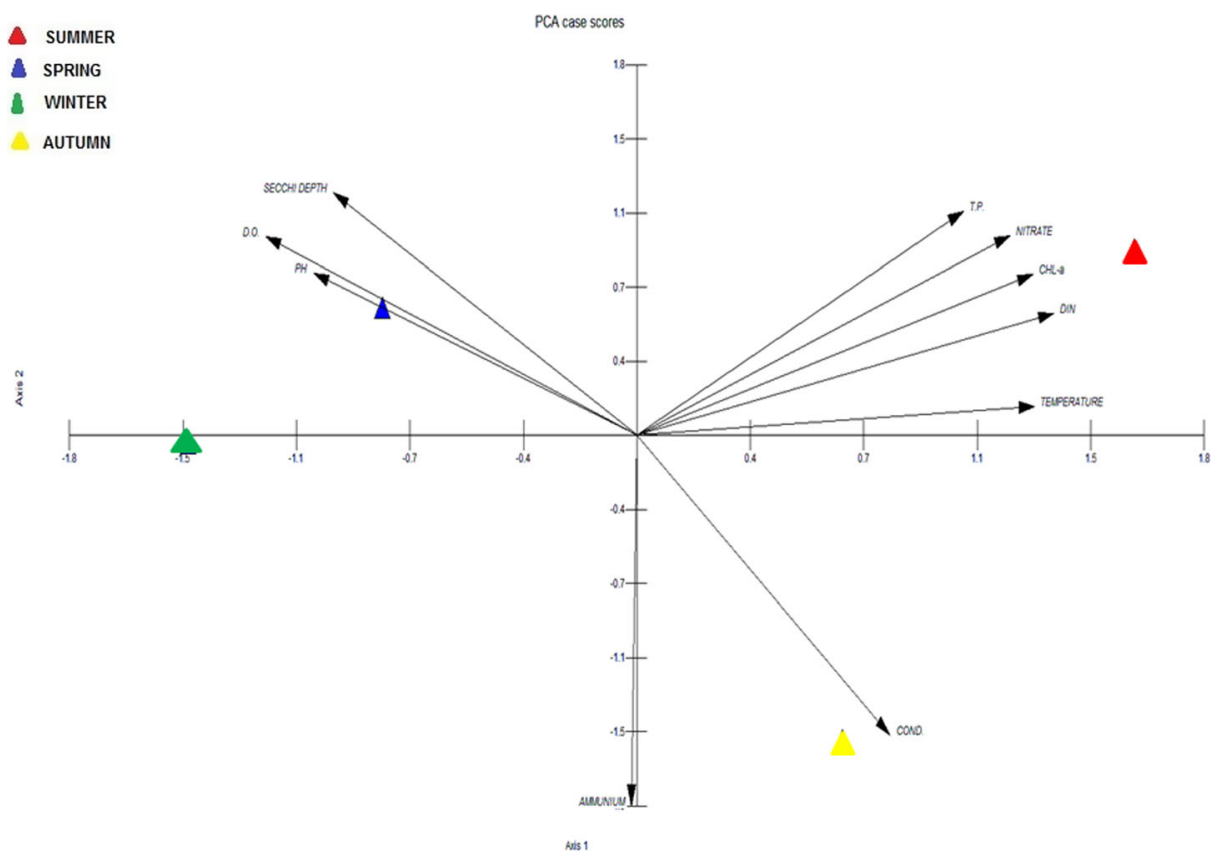

Fig. 3 Principal component analysis of the main water quality parameters for Lake Karla during the studied period. Axis percentage of explanation: Axis $157.7 \%$; Axis $235 \%$ 
Phosphorus and Nitrogen compounds, since Karla reservoir is a shallow, non-stratified water body, we could classify it into "moderate" class. Secchi depth is always lower than $0.6 \mathrm{~m}$, the mean total phosphorus value $(85 \mu \mathrm{g} / \mathrm{L})$ exceeds the threshold of $30 \mu \mathrm{g} / \mathrm{L}$, while the Inorganic Nitrogen fraction frequently exceeds the total nitrogen limit established for the "good" quality. Therefore, we can assume that the possibility to obtain a 'good' ecological status by 2015 is extremely weak.

\section{Conclusions}

Due to the complexity of the eutrophication process, which includes various physical, chemical and biological factors, it is important to take into account a wide spectrum of parameters for the evaluation of the trophic state in lakes and reservoirs. The restored Lake Karla has a European aspect, since it is the first re-constructed natural lake in Europe. The new lake Karla is exposed to point and diffuse pollution sources leading already to a progressive eutrophication with frequent occurrence of algal blooms. The protection of the watershed is considered as prerequisite for the improvement of the lake water quality. Lake Karla showed a spatial homogeneity throughout monthly monitoring while the seasonal trends can be explained by the changes in temperature, water clarity and the inputs of nutrients from the catchment. A comprehensive monitoring should be effective for both implementation of the WFD and for management purposes.

Acknowledgments An initial version of this paper was presented at the 8th International Conference of the EWRA in Porto, Portugal, June 26-29, 2013.

\section{References}

Álvarez Cobelas M, Catalán J, García de Jalón D (2005) Impacts on the continental aquatic ecosystems: Preliminary evaluation on the effects of climate change in Spain. In: Moreno JM (ed) Ministry of Environment, Madrid, pp 113-146

Ananiadis CI (1956) Limnological study of lake Karla. Bull Inst Océanogr Monaco 1083:1-19

APHA (2005) Handbook, of standard methods for the examination of water and wastewater, 21st edition. Published jointly by American Public Health Association, American Water Works Association, and Water Environment Federation

Araus JL (2004) The problems of sustainable water use in the Mediterranean and research requirements for agriculture. Ann Appl Biol 144:259-272

Beklioglu M, Romo S, Kagalou I, Quintana X, Becares E (2007) State of the art in the functioning of shallow Mediterranean lakes: workshop conclusions. Hydrobiologia 584:317-326

Chiaudani G, Premazzi G (1986) Eutrophication of European waters. DG XI Report, pp 113

EEA (1999) Nutrients in European ecosystems. European Environment Agency, Copenhagen

Gikas G, Yiannakopoulou T, Tsihrintzis VA (2006) Water quality trends in a coastal lagoon impacted by nonpoint source pollution after implementation of protective measures. Hydrobiologia 563:385-406

Guntner A, Carlos de araujo J, Bronstert (2004) A simple water balance modeling of surface reservoir systems in a large data-scarce semi-arid region. Hydrol Sci 49:901-918

Harper D (1992) Eutrophication of freshwaters - principles, problems and restoration. Chapman \& Hall, London, p 327

Jouni S (2011) Current trophic status of lake Karla, Greece, and proposals for remediation. Master thesis, University of Edinburgh, p 67

Kagalou I, Papadimitriou T, Bacopoulos V, Leonardos I (2008) Assessment of microcystins in lake water and the omnivorous fish (Carassius gibelio, Bloch) in Lake Pamvotis (Greece) containing dense cyanobacterial bloom. Environ Monit Assess 137:185-195 
Loukas A, Mylopoulos N, Vasiliades L (2007) A modeling system for the evaluation of water resources management strategies in Thessaly, Greece. Water Resour Manag 21(10):1673-1702

Markou D, Sylaios G, Tsihrintzis VA, Gikas G, Haralabidou K (2007) Water quality of Vistonis Lagoon, Nothern Greece: seasonal variation and impact of bottom sediments. Desalination 210:83-97

Ministry of Environment (2012) Management Plan of Thessaly Water District, Ministry of Environment, Energy and Climate Change, Athens (in Greek)

Mitsoura A, Papaioannou N, Berillis P, Mente E, Kagalou I, Papadimitriou T (2013) The presence of microcystins in fish Cyprinus carpio tissues: an histopathological study. Int Aquat Res 5:8. doi:10.1186/ 2008-6970-5-8

OECD (1982) Eutrophication of waters: monitoring, assessment and control. Organisation of Economic Cooperation and Development, Paris, p 154

Oikonomou A, Katsiapi M, Karayanni H, Moustaka-Gouni M, Kormas K (2012) Plankton microorganisms coinciding with two consecutive mass fish kills in a newly reconstructed lake. Sci World J 504135, 14 pages, doi: $10.1100 / 2012 / 504135$

Ozen A, Karapinar V, Kuruk I, Jeppesen E, Beklioglu M (2010) Drought induced changes in nutrient concentrations and retention in two shallow Mediterranean lakes subjected to different degrees of management. Hydrobiologia 646:61-72

Papadimitriou T, Katsiapi M, Kormas K, Moustaka-Gouni M, Kagalou I (2013) Artificially-born "killer" lake: phytoplankton based water quality and microcystin affected fish in a reconstructed lake. Sci Total Environ 452-453:116-124

Sánchez E, Gallardo C, Gaertner MA, Arribas A, Castro M (2004) Future climate extreme events in the Mediterranean simulated by a regional climate model: a first approach. Global Planet Chang 44:163-180

Scheffer M, Hosper H, Meijer L, Moss B, Jeppesen E (1993) Alternative equilibria in shallow lakes. Trends Ecol Evol 8:275-279

Scheffer M, Carpenter S, Foley A, Folke C, Walker B (2001) Catastrophic shifts in ecosystems. Nature 413:591596

Sidiropoulos P, Papadimitriou T, Stabouli Z, Loukas A, Mylopoulos N, Kagalou I (2012) Past, present and future concepts for conservation of the re-constructed Lake Karla (Thessaly-Greece). Fresenius' Environ Bull 21(10a):3027-3034

Skinner J, Zalewski S (1995) Functions and values of Mediterranean wetlands. A MedWet Publication. Tour du Valat, Arles, p 80

Wetzel RG (1990) Land-water interfaces: metabolic and limnological regulators. Verh Int Ver Limnol 24:6-24 